\title{
SIGNALING PRINCIPLES IN INTERACTIVE LEARNING MEDIA THROUGH EXPERT'S WALKTHROUGH
}

\author{
DERLINA \\ Physics Education Department \\ Universitas Negeri Medan \\ Medan, North Sumatera, Indonesia \\ Juhriyansyah DALLE \\ Information Technology Department \\ Universitas Lambung Mangkurat \\ Banjarmasin, South Kalimantan, Indonesia \\ Sutarto HADI \\ Mathematics Education Department \\ Universitas Lambung Mangkurat \\ Banjarmasin, South Kalimantan, Indonesia \\ Ariffin ABDUL MUTALIB \\ School of Multimedia Technology and Communication \\ Universiti Utara Malaysia \\ Sintok, Kedah, Malaysia \\ Candra SUMANTRI \\ IT Staff of PT. Global Adhi Pratama \\ Jakarta, Indonesia
}

\section{ABSTRACT}

This study analyzes the impact of signaling principles upon the effective use of interactive learning media. Normally, designers just design and develop learning media for use in schools without considering the way it eases users' tasks. Bearing in mind that signaling users while they are learning through interactive learning media is important, this study incorporates signaling principles while designing it. Thus, this paper aims to discuss the appropriate signaling principles for learning media from experts' perspective. The Iterative Triangulation Methodology was applied to achieve the aim. Altogether, activities were carried out in three phases: requirement analysis, design and development of the prototype, and expert evaluation using a walkthrough. Results revealed that although the prototype was designed by involving users, experts still discovered a number of flaws in the exercises as a result of not properly applying the signaling principles.

Keywords: Signaling, principles, walkthrough, interaction design, application.

\section{INTRODUCTION}

Multimedia has been used in improving the quality of teaching and learning process (Munadi, 2013). It makes learning contents more attractive, easily understood, more varied, and with an increased number of learning activities (Mayer, 2017), which implies in its design (Aziz, Mutalib, \& Sarif, 2015). When properly designed, multimedia learning could transform abstract concepts into concrete; bring the phenomenon of dangerous, rare or difficult to obtain to be presented into the class; present extremely fast-moving objects in a slow representation; allow students to interact directly with the environment; allow 
uniformity of observations and perceptions for student learning experience; generate motivation to learn; present learning information consistently and can be repeated or stored according to the need; and present the message or learning information simultaneously. In fact, Mayer (2017) goes beyond that, stating that it supports various tasks that enable learning to take place in a virtual environment. It is inline with the requirements of the fourth industrial revolution (4IR), which underline that the use of technology is absorbed into daily life, including education. Every society has to be ready to face it (Ward, 2016).

Considering such advantages, various studies have been carried out for the purpose of enriching the learning experience. As an example, Dolhalit, Salam, Mutalib, and Yusoff (2017) embedded persuasive principle in their multimedia learning in promoting awareness of truancy among disadvantaged students. Elkabani and Zantout (2015), and Aziz, Mutalib, and Sarif (2017) applied simplicity principle in their multimedia learning for visually-impaired learners in schools, while Tosho, Mutalib, and Abdul-Salam (2016) designed a multimedia learning to enhance inclusive education. Walsh, Petrie, and Odutola (2014) used multimedia to teach about culture. It was also used in teaching practical skills (Baharuddin \& Dalle, 2017), and in extremely-crowded situations (Al-Aidaroos \& Mutalib, 2015), which are part of the initiatives to prepare the society for facing the learning paradigm in the 4IR (Baygin, Yetis, \& Karakose, 2016; Li, Hou, \& Wu, 2017). One challenge in dealing with the 4IR is the ability to design solutions creatively (Carter, 2017).

Gardner expresses eight different types of intelligence through his Multiple Intelligences theory (Gardner, 1983; Gardner, 1993). One of them is visual intelligence, which argues that some people learn best through visual representation. In response to that, this study argues that multimedia learning will benefit students in their learning process (Tomita, 2017). It is especially applicable for the subjects (like physics) that contain processes involving difficult-to-get materials.

'Physics' originates from Greek, which means "natural." It is part of the science that studies the relevance of physical concepts with the real life, which consists of four dimensions: (1) way of thinking; (2) ways to investigate; (3) knowledge; and (4) its interaction with technology and society (Chiapetta \& Koballa, 2006). Many studies have been carried out to support the teaching and learning of physics. Regarding this, Doyan and Sukmantara (2014) developed an intranet for the physics course. They used the intranet to increase learners' various skills. Similarly, Stankova, Barmasov, Dyachenko, Bukina, Barmasova, and Yakovleva (2016) studied the efficiency of computer technology in learning physics. In fact, Toenders, De Putter-Smits, Sanders, and Den Brok (2017) worked with visually-impaired learners to solve their problems. Those studies focus mainly on providing contents in digital form, with various media representativeness. Besides physics, works in other science streams have also been carried out. As an instance, Aksoy (2012) utilized animation in teaching 7th-grade science and technology course. Meanwhile, Chiang, Yang, and Hwang (2014) used augmented reality, and Fautch (2015) used flipped classroom to enable learners to learn more actively.

However, ensuring learners are happy using the multimedia in learning is another issue. Accordingly, this study attempts to design a web-based learning media (as carried out by Butcher (2006)) for physics for use in schools in Indonesia. For the purpose of this study, static fluid is selected. It has been decided after observing the practices in schools. Through the observation, it was found that laboratories are abandoned, but topics are delivered through conventional lectures. It is because laboratories have limited tools for experiments, besides the inability of the laboratories to support a large number of students. As a result, learners feel bored learning physics topics. Those topics could be best learnt through experiencing them, so that they could visualize the processes and their effects. However, cost really matters in making all tools available. Thus, an alternative solution could be attempted. This could be overcome through the use of media technology, as demonstrated in the work of the researchers discussed in the previous paragraphs. 
Designing and developing interactive learning media must be tailored for the intended users, and appropriate for the context of use; who are, in this case, the school learners in Indonesia. Otherwise, such media cannot achievethegoals in thedesired way. The concern of this study is on learning experience, as recommended by Cooper, Reimann, Cronin, and Noessel (2014). Users tend to get frustrated when they experience difficulties in utilizing the learning materials (Preece, Sharp, \& Rogers, 2015), hence they do not engage with the learning activities and the learning contents. According to Sweller, Ayres, and Kalyuga (2011), eliminated exercises and reduced cognitive load are among factors that could increase user engagement in using interactive learning material. Among the famous ways to ensure that is by considering certain principles in designing the product (Clark, 2014). In response to that, this study applies signaling principles in designing the web-based interactive learning media, as recommended by Mayer (2014), and Mautone and Mayer (2001). It is one of the principles in multimedia learning (Butcher, 2014). It has to go through a scientific and systematic process (Mayer, 2009; Mayer 2011). Thus, this paper aims to demonstrate the expert review of the web-based learning media.

This section discusses the background of this study, including the problem to be solved. Next, the research procedure is explaned. Then, the results and findings are presented. Finally, this paper ends with a discussion ofthe impact of this study on the context.

\section{METHOD}

This study involves three parts; requirement analysis, development, and evaluation; which require iterations of processes. In fact, there are a number of iterated data sources and methods. To fit these requirements, this research adopts the Iterative Triangulation Methodology. The triangulated data source and methods are visualized in Figure 1. Triangulation is applied in terms of data source, method, theory, and data analysis.

> Data source triangulation - this study gathers data from different time, space, and persons. This increases the possibility of revealing a typical data or the potential of identifying similar patterns, thus increasing the confidence of the findings.

$>$ Methodological triangulation - could also be called mixed-method or multimethod, and can be seen in both data collection method and research method. Use of different methods provides richer information to the study.

Further, Figure 2 visualizes the steps carried out throughout the research work mapped with the deliverables.

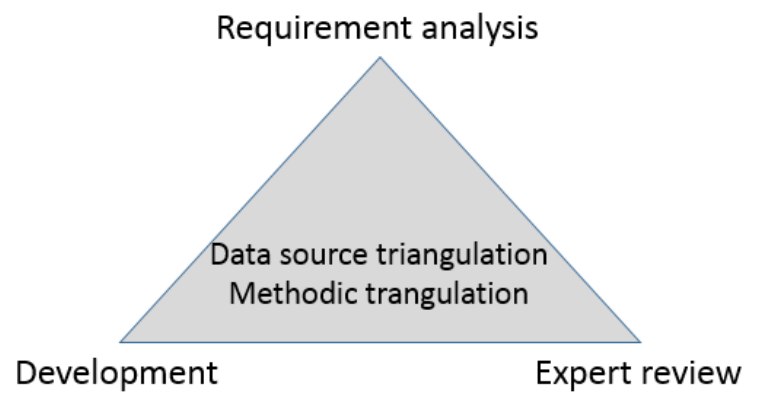

Figure 1. Triangulation Methodology 


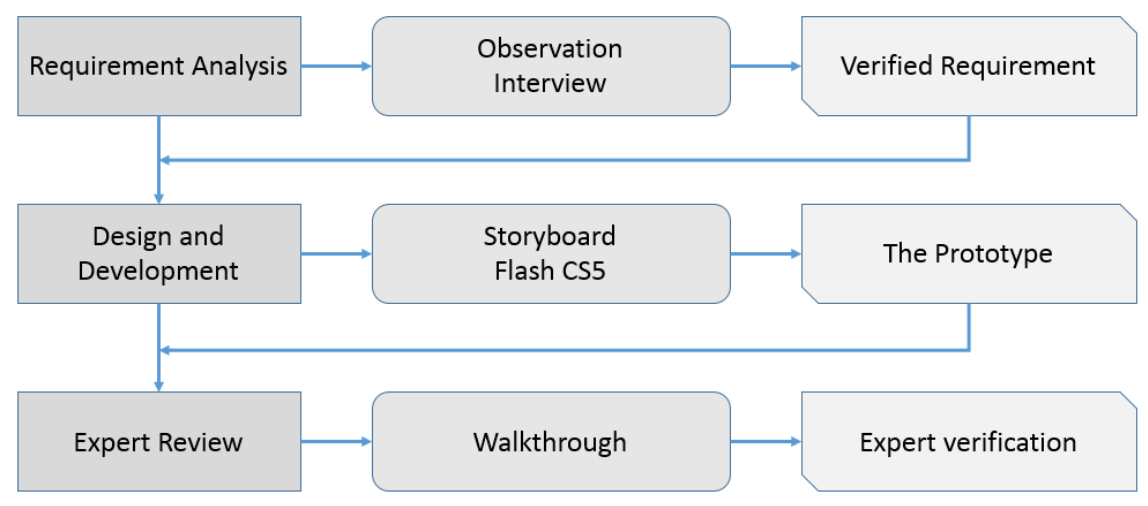

Figure 2. Research Methodology

Figure 2 shows that the requirements were gathered through observation and interview. Upon commencement of this study, having understood the problem, as discussed in the Introduction section, this study observed the teaching and learning in the classroom. The teaching and learning practices in three schools in Banjarmasin and three schools in Medan were observed. Prior to the observation, this study made a proper arrangement with the management of the schools. At this point, where the goal of the observation was to understand the current state of teaching and learning practices, observing six schools is sufficient, because the six schools already cover rural and urban areas, running standard curricula by receiving funds from the government. In the observation, it was found that teachers teach in a conventional way, and learners do not participate. It is totally bookbased, and learners show no excitement. In each school, after a few sessions of observation, this study interviewed the teachers. The interviews were held in schools, where they teach. Altogether, 19 teachers involved in the interview (between 1 and 3 teachers each school). The aim of the interview was to gather their view on the use of visual representation (multimedia learning application) in their teaching and learning on top of the book. Also, it was aimed to gather additional input to see if they are happy with the multimedia learning application.

Feedbacks of the interview were obviously as expected. The teachers favored the idea of utilizing multimedia learning application for their classroom teaching. In further discussion, the teachers agreed to select static fluid as a start. Particularly, they emphasized that Pascal law, submarine, regional water company, and principal of Archimedes are the topics that must be made available. It was decided that the topic is hardly explained with a visual representation, especially because it requires special setting and tools. When it could be visualized using multimedia learning application, it could better support their teaching and learners' understanding.

Having interviewed the teachers, this study interviewed the learners, aimed at gathering their views on the way they expect the application to support their learning. As the aim was general, this study selected between 2 and 5 learners each school (eventually this study managed to interview 32 learners). The interviews were also held in schools, where they study. Based on their feedback, they prefer a web-based application so that they could access the learning content anytime anywhere. They have no idea about how the application will look and feel, but they just need an application that is friendly to them.

Based on the results of the observations and interviews, the researchers concluded that the users need an interactive learning media that provides contents on static liquid (particularly on Pascal law, submarine, regional water company, and principal of Archimedes) for them to access any time anywhere. For this study, the content on the static liquid is taken from the textbook, while the focus is to make the learning media usable for the users. Particularly, the learning media should minimize users' cognitive load by minimizing exercises. 
Based on the requirements, the prototype was designed. Ideas were put on a storyboard (the sample is available in Figure 3). It was used to elicit feedback from the users.
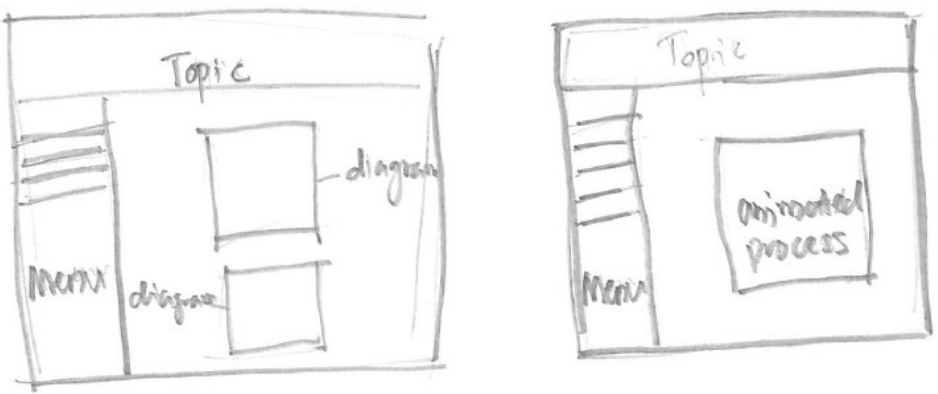

Figure 3. Sample of the Storyboard

The storyboard was presented to the users in a cyclical process, for them to give their comments and feedback on the design. The sample in Figure 3 is the finalized design, in which they prefer an application with windowing and menu interaction style.

Then, the design was transferred into a working prototype. Flash CS5 was used in making animated representations. Figures 4 through 7 depict some of the snapshots of the learning media.

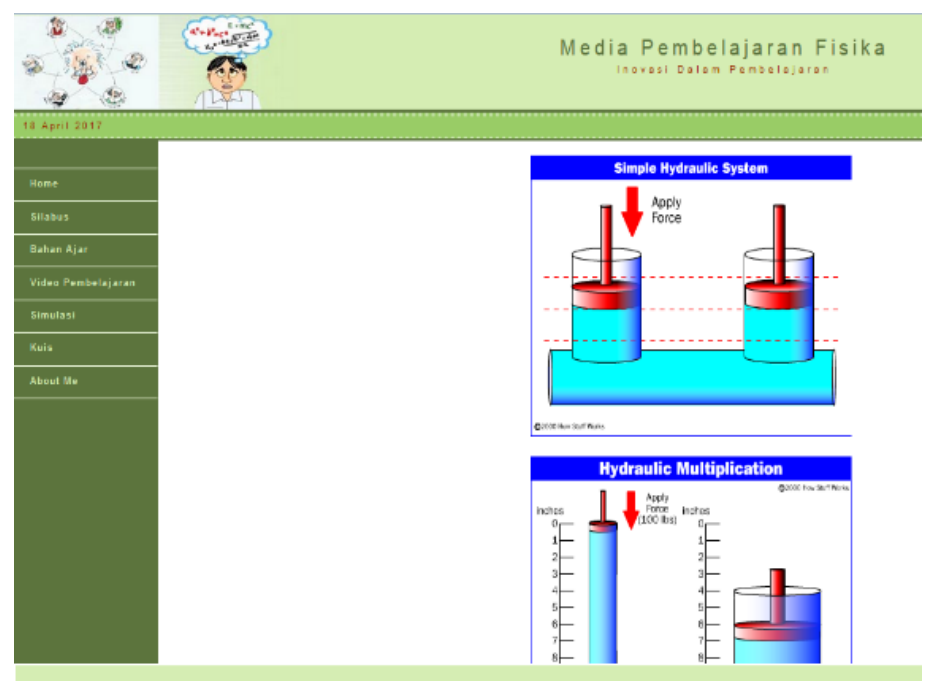

Figure 4. Appearance of Law Pascal Application Menu On Hydraulic Pump

Figure 4 displays the learning media with the navigation panel on the left. The background is made plain, to avoid unnecessary mental processing. The topic remains at the top at all time. In Figure 4, when users click the arrow, a window opens and displays a simulation as seen in Figure 5. The process is represented by colors and text in an enlarged size. 

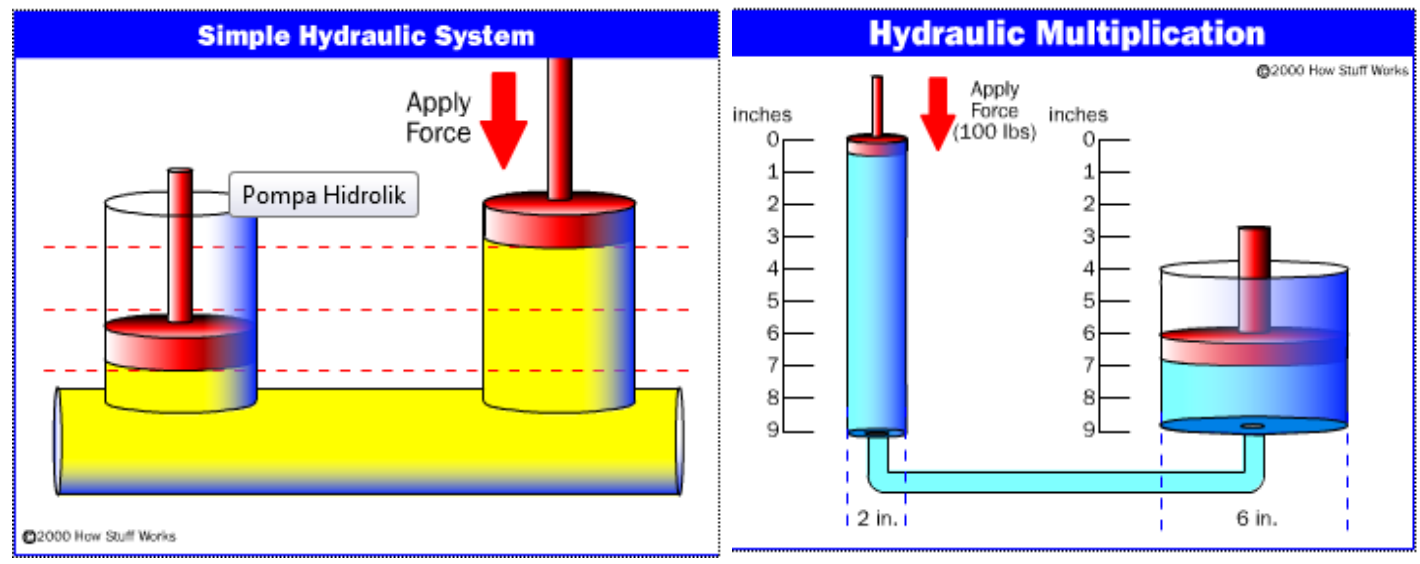

Figure 5. Pascal Legal Applications on the Hydraulic Pump

Figure 6 is a submenu display that shows the phenomenon of Archimedes Principle. In the media the student can observe if the object is inserted into the liquid then the weight of the load will decrease as much as the liquid it displaces, by changing the load inserted into the liquid the amount of water that moves will also vary, thus displaying a different appearance.
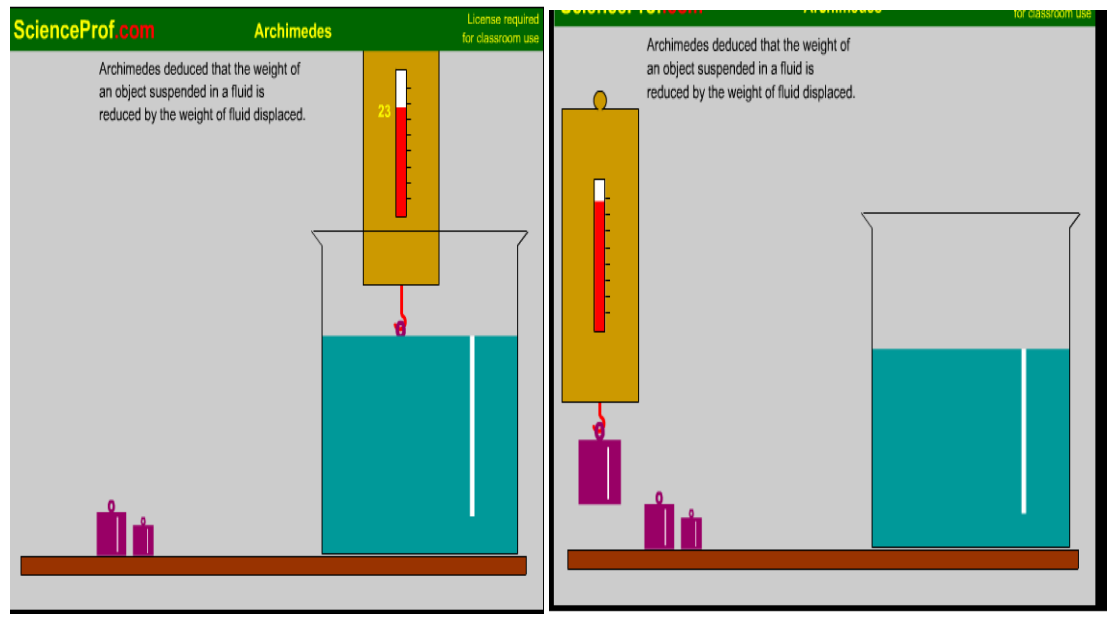

Figure 6. The Archimedes Principle

Figure 7 is a submenu display that shows the application of Archimedes in everyday life especially on submarines, students can observe and manipulate the conditions of floating submarines and diving.

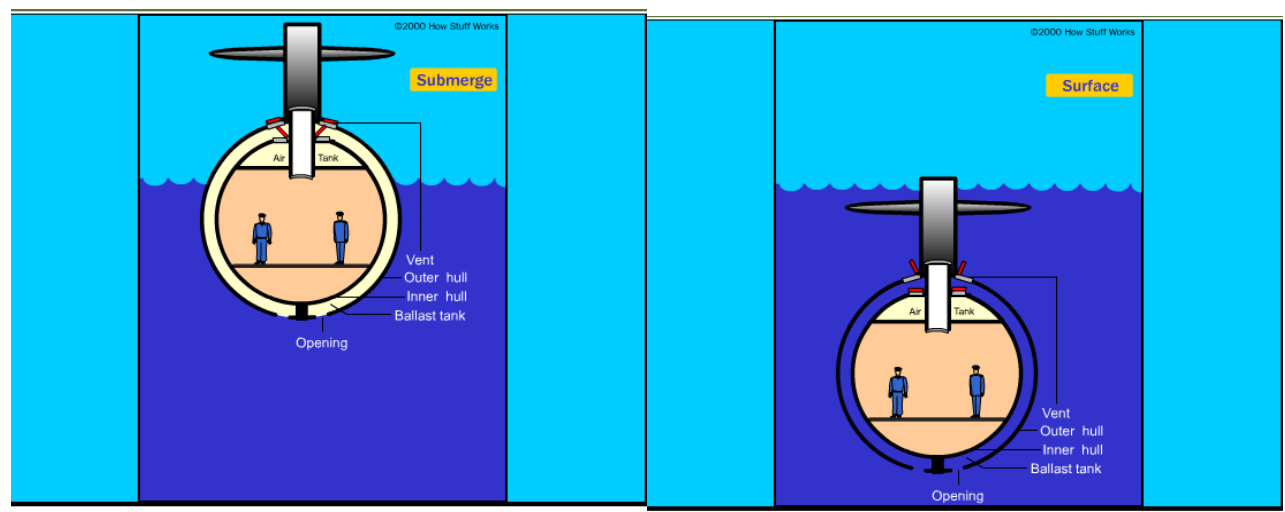

Figure 7. Applications of Archimedes on submarines 
Then, the prototype was tested through expert review, in which walkthrough was performed to determine whether through the designed interface users could easily carry out their tasks or not (Blackmon, Polson, Muneo, \& Lewis, 2002). Five experts were involved in the walkthrough sessions. All experts had been teaching in the field of humancomputer interaction and research for at least seven years. In addition, projects in the industry were also consulted. The procedure for the walkthrough session is visualized in Figure 8.

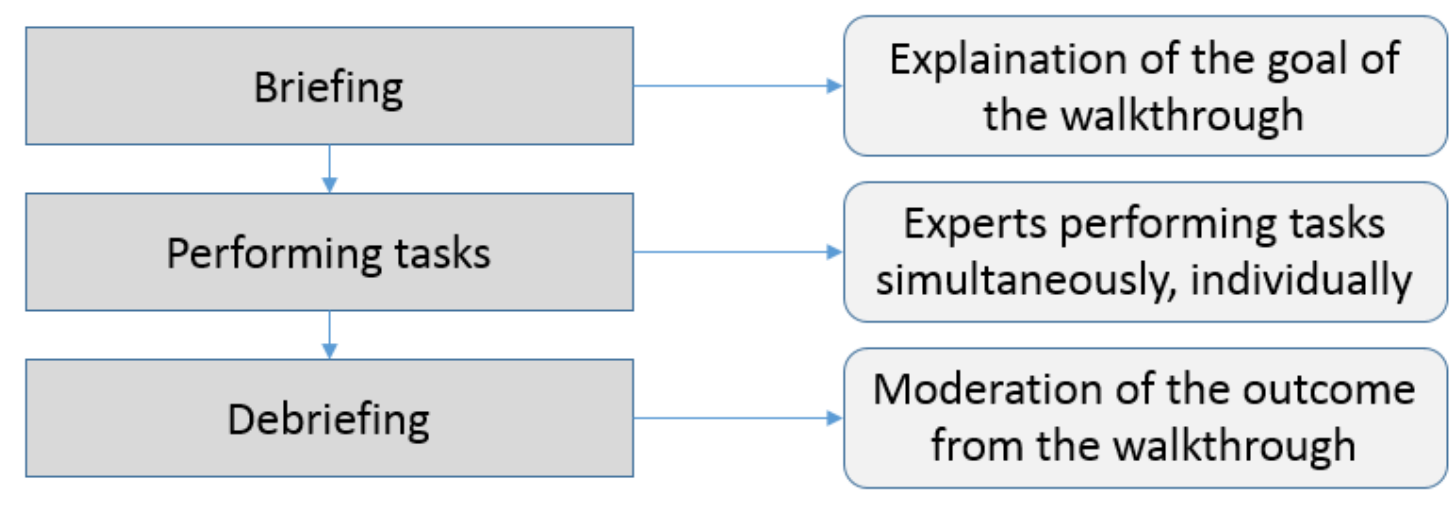

Figure 8. The Walkthrough Procedure

Referring to Figure 8, in the beginning, the experts gathered together and were briefed about the goal of the walkthrough. They were made understood that the walkthrough was aimed at gathering usability issues, particularly on flaws that increase cognitive loads through unnecessary exercises. Then, they were walked through the learning media, guided by specific tasks. The tasks are (1) observe the simulation for Pascal law, (2) observe the simulation for a submarine, (3) observe the simulation for the regional water company, and (4) observe the simulation for the Archimedes Principle. While walking through the learning media, each of the experts noted down all the flaws that they found. They were not allowed to discuss during this walkthrough. Later, in the debriefing session, the experts sat together and discussed what they had found. They brainstormed, and moderated the outcomes. Finally, they handed the outcomes to the researchers of this study.

\section{RESULTS}

The learning media was developed based on the storyboard that was designed with user intervention. The contents were adopted from the textbook. When experts walked through the learning media, their concern was whether the prototype, through the way it interacts with the users, support the user tasks well. In this paper, the user tasks being evaluated is related to observing the simulations to understand the content.

Having gone through the walkthrough process, the experts found that the learning media is able to deliver the contents. However, the users face certain difficulties in some tasks. Table 1 details these difficulties in the tasks. 
Table 1. Excise in the Learning Media

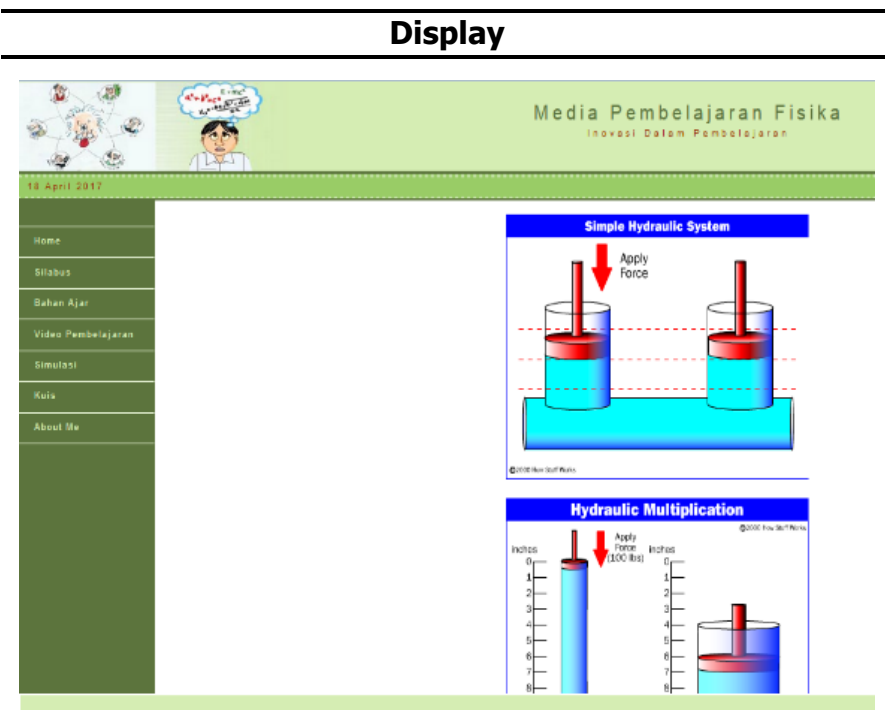

Excise and Implication

Excise 1. There is no instruction for the users.

Implication: When there is no instruction, users have to guess for their action (can cause cognitive load). They may make mistakes, or wait for some actions from the learning media (can lead to stress).

Excise 2. The arrows have no indication of an active button.

Implication: When there is no indication, users do not realize that they can be clicked for actions from the learning media, hence, they have to guess and may click on other elements (can cause cognitive load).

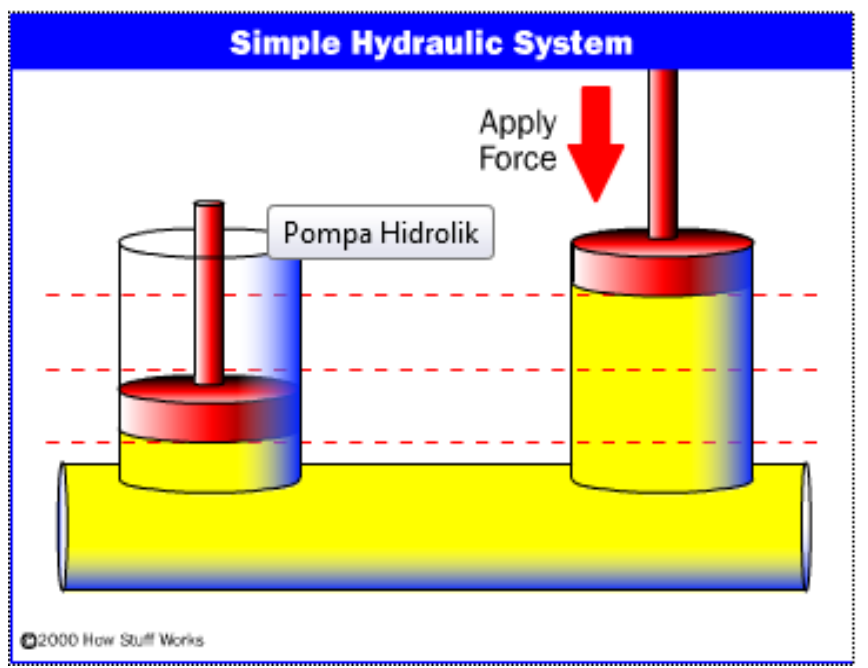

Excise 3. The objects have no label.

Implication: When there is no label, users have to guess. Perhaps, users have to find the information from another source (can cause unnecessary action and cognitive load).

Excise 4. The lines have no label.

Implication: There are three lines, with no label, hence users have to guess which one means what... (can cause cognitive load).

Excise 5. Does the color (for the objects) contain certain meaning?

Implication: Users may think the color is part of the effects of the simulated action. Hence, they tend to think of the effect (can cause cognitive load).

Excise 6. The arrow does not indicate the strength of the force.

Implication: Users have no idea, and they have to make some guesses (can cause cognitive load). Or they understand differently. 


\section{Hydraulic Multiplication}
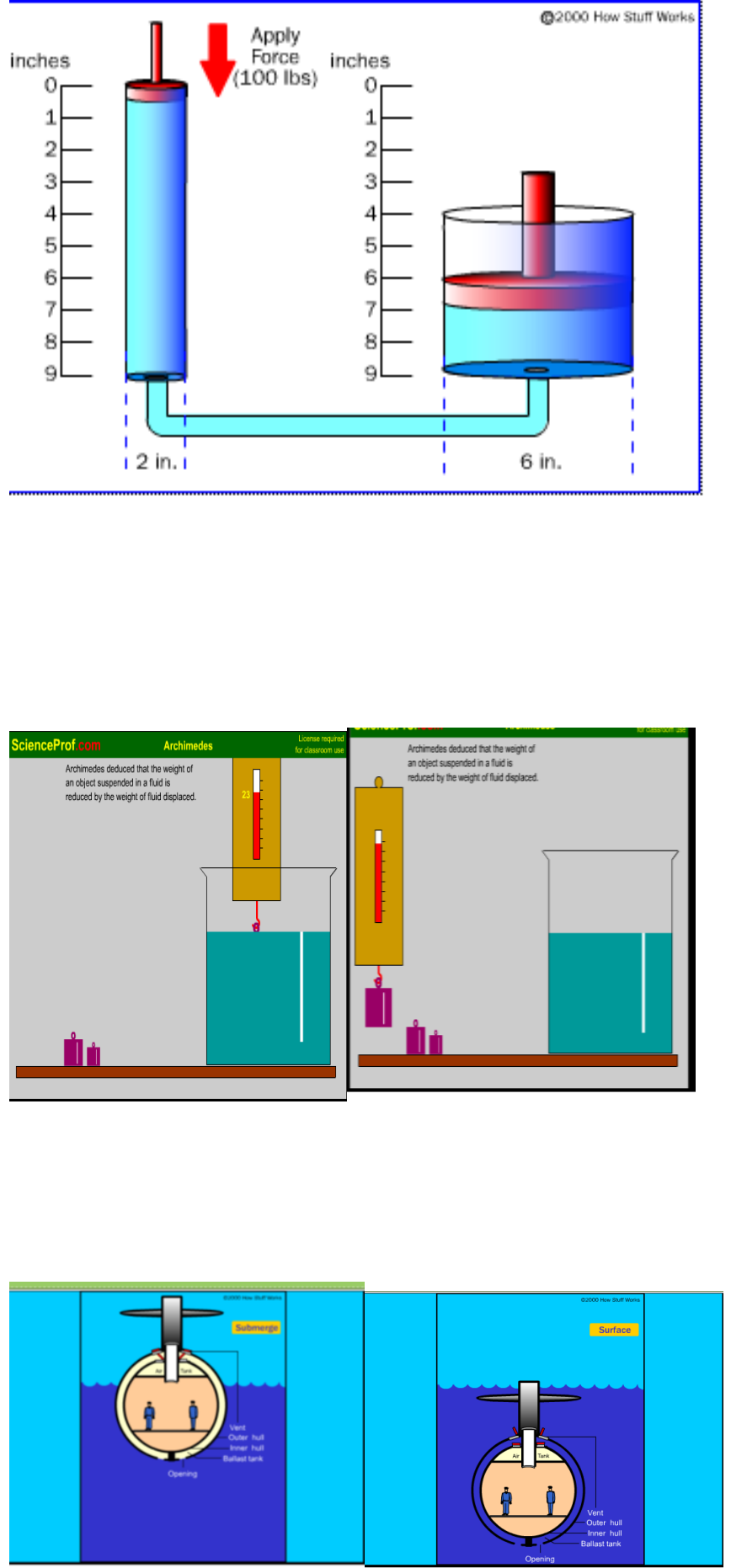

Excise 7. The objects have no label.

Implication: When there is no label, users have to guess. Perhaps, users have to find the information from another source (can cause cognitive load).

Excise 8. The experiment seems similar to the simple hydraulic system, but has no line.

Implication: Users may wonder in what way the simulation results in (can cause cognitive load).

Excise 9. Objects use a different color than that in the simple hydraulic system.

Implication: Users may think color means something (can cause cognitive load).

Excise 10. The objects have no label.

Implication: When there is no label, users have to guess. Perhaps, users have to find the information from another source (can cause cognitive load).

Excise 11. There is no indication for user tasks.

Implication: Users have to guess their actions (can cause cognitive load).

Excise 12. The objects have no label.

Implication: When there is no label, users have to guess. Perhaps, users have to find the information from another source (can cause cognitive load).

Excise 13. There is no indication for user tasks.

Implication: Users have to guess their actions (can cause cognitive load).

Excise 14. The label is too small.

Implication: Users have to put extra effort into reading the label (can cause cognitive load). 
Implication: Users have to rely too much on the visual and audio. The text could strengthen the audio and visual. Hence, without text stating important points, learning could be distorted (could cause cognitive load).

Excise 16. No example in the actual context.

Implication: Users may not be able to associate the experiment with the actual context. Hence, they have to guess, or it creates fear for them to experience the actual situation (could cause frustration).

\title{
DISCUSSIONS AND CONCLUSION
}

\begin{abstract}
Although the learning media has been designed by involving users, and their feedbacks were considered, and signaling principles have been applied, still experts found that users will face difficulties understanding contents from the experiments exhibited in the learning media. Based on their experience while walking through the learning media, they suggest actions in Table 2 to be taken.
\end{abstract}

Table 2. Recommendations for Improvement

\begin{tabular}{|c|c|}
\hline & Excise and Recommendation \\
\hline Excise 1. & $\begin{array}{l}\text { There is no instruction for the users. } \\
\text { Recommendation: Instructions are placed for every experiment. They have to be step-by-step } \\
\text { in the language users familiar most, with a placeholder. }\end{array}$ \\
\hline Excise 2. & $\begin{array}{l}\text { The arrows have no indication of an active button. } \\
\text { Recommendation: when there are elements users are expected to click, make them } \\
\text { noticeable. They have to provide cues, either visual cue or audio cue. }\end{array}$ \\
\hline Excise 3. & $\begin{array}{l}\text { The objects have no label. } \\
\text { Recommendation: In all experiments, all objects are labeled. The label should not touch the } \\
\text { object, and located on a placeholder. For all objects, the label has to be easily read and } \\
\text { standardized (color, shape, font size, etc...) }\end{array}$ \\
\hline Excise 4. & $\begin{array}{l}\text { The indication of effects and results have no label. } \\
\text { Recommendation: All indications of effects and results in all experiments should be } \\
\text { labeled/captioned. The labels must be represented differently than the labels for objects. They } \\
\text { must be standardized for all experiments. }\end{array}$ \\
\hline Excise 5. & $\begin{array}{l}\text { Does the color (for the objects) contain certain meaning? } \\
\text { Recommendation: If the use of color is insignificant, use standardized color for all objects. }\end{array}$ \\
\hline Excise 6. & $\begin{array}{l}\text { The arrow does not indicate the strength of the force. } \\
\text { Recommendation: When there is a force, indicate the strength of the force, in the text. }\end{array}$ \\
\hline Excise 7. & $\begin{array}{l}\text { The experiment seems like similar to the simple hydraulic system, but has no line. } \\
\text { Recommendation: For all similar experiments, with similar form of effects, use similar } \\
\text { representation. }\end{array}$ \\
\hline Excise 8. & $\begin{array}{l}\text { Objects use a different color than that in the simple hydraulic system. } \\
\text { Recommendation: For all similar procedure of experiments, use similar representations. }\end{array}$ \\
\hline Excise 9. & $\begin{array}{l}\text { There is no indication for user tasks. } \\
\text { Recommendation: For all experiments, user tasks have to be clearly indicated, such as } \\
\text { whether they have to click something, type something, drag somewhere, and etc... }\end{array}$ \\
\hline Excise 10. & $\begin{array}{l}\text { The label is too small. } \\
\text { Recommendation: When providing text, ensure the text is readable by the users. This implies } \\
\text { to color, size, location, contrasts, etc... }\end{array}$ \\
\hline Excise 11. & $\begin{array}{l}\text { The simulations lack caption explaining the experiment. } \\
\text { Recommendation: On top of audio and visual explanation, text stating main points is } \\
\text { necessary. Provide them to enhance memorability. }\end{array}$ \\
\hline Excise 12. & $\begin{array}{l}\text { No example in the actual context. } \\
\text { Recommendation: Provide video showing how the context being experimented takes place in } \\
\text { the real situation. }\end{array}$ \\
\hline
\end{tabular}


The results of the walkthrough prove that although an interactive learning media is designed with users' involvement, it is not guaranteed flaw-free. Designers have to realize that designing learning media has to be carried out in an interdisciplinary team (Preece, Rogers, \& Sharp, 2015). In this study, not only content experts were involved, besides learners, but also experts in human-computer interaction.

Involving experts in human-computer interaction is crucial because they could determine the problems users potentially faced when dealing with the learning media. This could not be performed by other people, including the designer. Based on their experience the human-computer interaction experts have user characteristics in mind already, for the context they are using the learning media. As a result, identifying flaws is easy for them.

Other studies like Karajeh, Hamtini, and Hamdi (2016) and Mohd and Shahbodin (2016) also involved experts in their development of interactive products. Basically, they also gathered similar results, that expert evaluation discovers a number of flaws in terms of excise in their interactive products.

All recommendations by the experts are expressed in ensuring users are notified. This is the role of signaling principles. Obviously, signaling principle is important in guiding users while going through the learning media (Austin, 2009). It helps users in many ways. Besides noting users of buttons and menu, it helps to feed reactions back to users, and notifying the status of tasks being carried out. Also, it clarifies format of entry, and availability of something (Amadieu, Marine, \& Laimay, 2011). Obviously, it is more powerful when the interactive application is more complex. Anyway, the learning media in this study is simple; hence, the signals it provides to users are limited. It is in line with the goal of the learning media (and any other interactive application), which is to ease user tasks. Hence, unnecessary signaling is totally avoided.

The interactive learning material in this study acknowledges the roles of experts in humancomputer interaction. It is strongly emphasized by many gurus (like Preece, Rogers, and Sharp (2015) and Mayhew (1999)) to employ experts for evaluating the interface of the designed prototype before deployment. Based on the recommendations by the experts, this study will take the appropriate actions in improving the interface.

Further, this study intends to carry out a user test after the prototype is improved. Besides expert evaluation, this study believes that user test is also important before the learning media is deployed, as has been carried out by various works previously (Aziz, Roseli, \& Mutalib, 2011; Mayer \& DaPra, 2012). In fact, it is also strongly emphasized by the experts like Nielsen (1994), Preece, Rogers, and Sharp (2015), Schneiderman, Plaisant, Cohen, Jacobs, Elmqvist, andDiakopoulos (2016).

Regarding signaling principles, designers have to understand that too much signaling is also annoying users (Mayer, Heiser, \& Lonn, 2001; Mayer \& Fiorella, 2014). It is analogous to a person who tells too much, even in situations where people do not expect any information. When the person keeps telling, and others have to respond to it, it is unnecessary. Hence, providing signals to users should be carefully considered, to ensure important signals are not leftunattended, and that no unnecessary signal is loaded.

ACKNOWLEDGEMENTS: This paper is coming from lecturer-student collaboration research with self-funding. We would like to express our gratitude to Universitas Negeri Medan, Universiti Utara Malaysia, and Universitas Lambung Mangkurat for their support particularly facilities and infrastructures. 


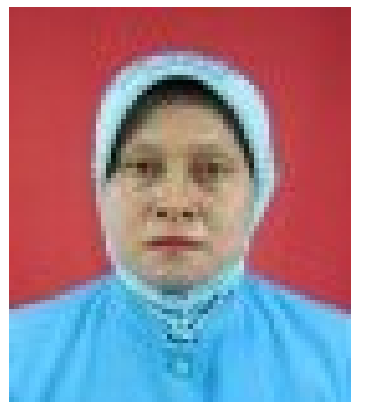

DERLINA is a lecturer at Universitas Negeri Medan, Indonesia. She gained her Master Degree and Doctoral Degree from Universitas Sumatera Utara Medan in 2001 and Universitas Negeri Jakarta in 2012 Indonesia. Now she is the secretariat of graduate program of physics education department Universitas Negeri Medan. Her main research interest is physics education with relating to educational technology.

\section{DERLINA}

Department of Physic Education

Universitas Negeri Medan, Medan, Indonesia

Phone: +62- 61-7352234

Mobile: +62-81210161520

E-mail: derlina@unimed.ac.id

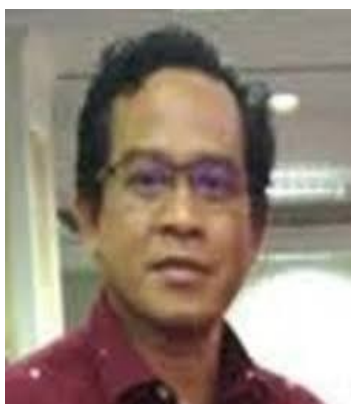

Juhriyansyah DALLE is a lecturer at Department of Information Technology Universitas Lambung Mangkurat, Banjarmasin Indonesia. He gained his Master Degree in Computer Sciences from Universitas Gadjah Mada in 2003, and Doctoral Degree from Universiti Utara Malaysia in 2010. His academic interest areas are Information studies, multimedia content, educational technology and media, area of expertise, human-computer interaction, and usability, computers in education, information system development and applied statistics in education and information technology. He has 5 journal articles published in international indexes, 1 national and $\mathbf{2}$ international proceedings indexes.

Juhriyansyah DALLE

Department of Information Technology, Faculty of Engineering

Universitas Lambung Mangkurat, Banjarmasin, Indonesia

Phone: +62-511 4311668

Mobile: +62-81312979899

E-mail: j.dalle@ulm.ac.id

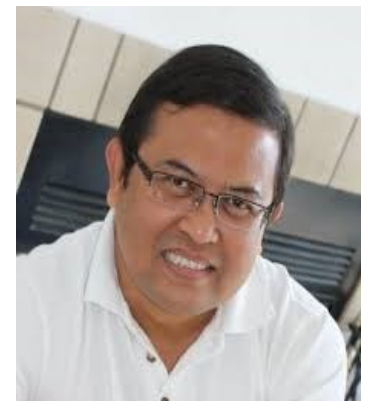

Sutarto HADI is a Professor of Mathematics Education at Faculty of Education Universitas Lambung Mangkurat Banjarmasin Indonesia who has more than twenty years of experience working for teaching mathematics education subjects. Currently he has been assigned as the rector of Universitas Lambung Mangkurat Indonesia. His main area of research interest is realistic mathematics.

\section{Sutarto HADI}

Department of Mathematics Education, Faculty of Teacher Training and Education Universitas Lambung Mangkurat, Banjarmasin, Indonesia

Phone: +62-511-3306603

Mobile: +62-82152750522

E-mail: shadiunlam@gmail.com 


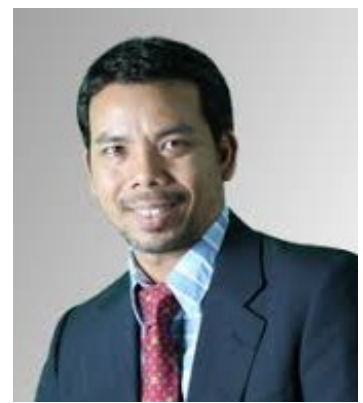

Ariffin ABDUL MUTALIB is a lecturer of Multimedia Technology Department, School of Multimedia Technology and Communication, Universiti Utara Malaysia, Malaysia. He hold PhD IT from Universiti Utara Malaysia in 2009 and Master Degree in Interactive Multimedia form Heriot-Watt University Scotland UK. Her academic interest areas are Information studies, multimedia content, educational technology and media, area of expertise, humancomputer interaction, usability, computers in education.

Ariffin ABDUL MUTALIB

School of Multimedia Technology and Communication, Universiti Utara Malaysia, Sintok, Kedah, Malaysia

Phone: +604 - 9285802

E-mail: am.ariffin@uum.edu.my

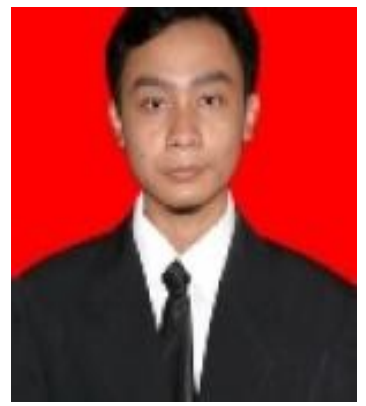

Candra SUMANTRI is an alumni of Department of Physic Education Universitas Negeri Medan, Indonesia. He is concerning on information technology development and now he is Information Technology staff of PT. Global Adhi Pratama one company engaged in the field of services and distribution of IT products, especially in the field of security.

\section{Candra SUMANTRI}

IT Staff of PT. Global Adhi Pratama

Jl. Meruya Ilir No. 88, Business Park Kebun Jeruk Blok E2-8s, Jakarta Barat

Jakarta, Indonesia

Phone: +62-21-80681233

E-mail: candra.sm3@gmail.com

\section{REFERENCES}

Aksoy, G. (2012). The Effects of Animation Technique on the 7th Grade Science and Technology Course. Creative Education. June 2012. Vol.3, No.3, 304-308. doi:10.4236/ce.2012.33048.

Al-Aidaroos, A. S. A., \& Mutalib, A. A. (2015). Personal digital mutawwif: A multi-modal mobile hajj assistance using the location-based services. Jurnal Teknologi. 77(29). 15-20.

Amadieu, F., Marine, C., \& Laimay, C. (2011). The attention-guiding effect and cognitive load in the comprehension of animations. Computers in Human Behavior. 27(1). 36-40.

Austin, K. A. (2009). Multimedia learning: Cognitive individual differences and display design techniques predict transfer learning with multimedia learning modules. Computers and Education. 53(4). 1339-1354.

Aziz, N., Roseli, N. H. M., \& Mutalib, A. A. (2011). Visually impaired children's acceptance on assistive courseware. American Journal of Applied Science. 8(10). 1019-1026.

Aziz, N., Mutalib, A. A., \& Sarif, S. M. (2015). The design principles of assistive courseware for low vision (AC4LV) learners. ARPN Journal of Engineering and Applied Sciences, 10 (3), pp. 1447-1456. 
Aziz, N., Mutalib, A. A., \& Sarif, S.M. (2017). User experience of interactive Assistive Courseware for Low Vision learners (AC4LV): Initial round. TEM Journal. 6(3). 488-496.

Baharuddin, \& Dalle, J. (2017). Interactive courseware for supporting learners competency in practical skills. Turkish Online Journal of Educational Technology. 16(3). 87-98.

Baygin, M., Yetis, H., Karakose, M., \& Akin, E. (2016). An effect analysis of industry 4.0 to higher education. The 15th International Conference on Information Technology Based Higher Education and Training, ITHET. 7760744.

Blackmon, M. H., Polson, P. G., Muneo, K., \& Lewis, C. (2002). Cognitive Walkthrough for the Web. CHI 2002، 4(1). 463-470.

Butcher, K. R. (2006). Integrating Visual and Verbal Knowledge During Classroom Learning with Computer Tutors. (kbutcher@pitt.edu).

Butcher, K. R. (2014). The multimedia principle in multimedia learning. In R. E. Mayer (Ed.), The Cambridge handbook of multimedia learning. New York: Cambridge University Press

Carter, D. (2017). Creativity in action - the information professional is poised to exploit the fourth industrial revolution: The business information survey 2017. Business Information Review. 34(3). 122-137.

Chiang, T. H. C., Yang, S.-J.-H., \& Hwang, G.-J. (2014). An Augmented Reality-based Mobile Learning System to Improve Students' Learning achievements and Motivations in Natural Science Inquiry Activities. Educational Technology \& Society, 17(4), 352-365.

Chiapetta, \& Koballa (2006). Science Instruction in the Middle and Secondary Schools: Developing Fundamental Knowledge and Skills for Teaching, sixth edition, New Jersey: Pearson Education, Inc.

Clark, R. C. (2014). Multimedia Principles in e-Courses. In R. E. Mayer (Ed.), The Cambridge handbook of multimedia learning. New York: Cambridge University Press.

Cooper, A., Reimann, R. Cronin, D., \& Noessel, C. (2014). About Face: The Essentials of Interaction Design, $4^{\text {th }}$ Ed. Wiley.

Dolhalit, M. L., Salam, S. N. A., Mutalib, A. A., \&Yusoff, M. S. B. (2017). Towards the development of Persuasive Multimedia Model of Truancy Awareness (PMTA): Review of research. Journal of Engineering and Applied Sciences, 12(16). 42154221

Doyan, A., \& Sukmantara, I. K. Y. (2014). The Development of Physics Intranet Web to Improve the Concept Comprehension and Problem Solving Skills of the Students of SMK. Jurnal Pendidikan Fisika Indonesia 10 (2), 117-127. doi: 10.15294/jpfi.v10i2.3348.

Elkabani, I., \& Zantout, R. (2015). A framework for helping the visually impaired learn and practice math. 2015 5th International Conference on Information and Communication Technology and Accessibility, ICTA 2015

Fautch, J. M. (2015). The Flipped classroom for teaching organic chemistry in small classes: Is it effective? Chemistry Education Research and Practice, 16(1), 179186. doi:10.1039/c4rp00230j.

Gardner, H. (1983). Frames of Mind. New York: Basic Book Inc.

Gardner, H. (1993). Multiple Intelligences: The Theory in Practice, NY. Basic book 
Karajeh, W., Hamtini, T., \& Hamdi, M. (2016). Designing and implementing an effective Courseware for the Enhancement of e-learning. International Journal of Emerging Technologies in Learning. 11(4). 70-76.

Li, G., Hou, Y., \& Wu, A. (2017). Fourth Industrial Revolution: technological drivers, impacts and coping methods. Chinese Geographical Science. 24(7). 626-637.

Mautone, P. D., \& Mayer, R. E. (2001). Signaling as a cognitive guide in multimedia learning. Journal of Educational Psychology. 93. 377-389.

Mayer, R. E., \& DaPra, C. S. (2012). An embodiment effect in computer-based learning with animated pedagogical agent. Journal of Experimental Psychology: Applied, 18, 239-252.

Mayer, R. E., Heiser, H., \& Lonn, S. (2001). Cognitive constraints on multimedia learning: When presenting more material results in less understanding. Journal of Educational Psychology, 93, 187-198.

Mayer, R. E. (2017). Using multimedia for e-learning. Journal of Computer Assisted Learning. 33(5). 403-423.

Mayer, R. E. (2009). Multimedia learning (2nd ed). New York: Cambridge University Press.

Mayer, R. E. (2011). Applying the science of learning. Upper Saddle River, NJ: Pearson.

Mayer, R. E. (2014). Principles based on social cues: Personalization, voice, image, and embodiment principles. In R. E. Mayer (Ed.), The Cambridge handbook of multimedia learning. New York: Cambridge University Press.

Mayer, R. E., \& Fiorella, L. (2014). Principles for reducing extraneous processing in multimedia learning: Coherence, signaling, redundancy, spatial contiguity, and temporal contiguity principles. In R. E. Mayer (Ed.), The Cambridge handbook of multimedia learning. New York: Cambridge University Press.

Mayhew, D. J. (1999). The Usability Engineering Lifecycle. Morgan Kaufmann, San Francisco

Mohd, C. K. N. C. K., \& Shahbodin, F. (2016). Design and development of a multimedia courseware using personalized learning environment approach for nutrition topic. ARPN Journal of Engineering and Applied Sciences. 11(18). 10714-10720.

Munadi, Y. (2008). Learning Media - A New Approach. Jakarta: Gaung Persada Press.

Nielsen, J. (1994). Usability Engineering. Morgan Kaufmann Publishers Inc.

Preece, J., Sharp, H., \& Rogers, Y. (2015). Interaction Design: Beyond Human-Compter Interaction $4^{\text {th }}$ Ed. Wiley.

Schneiderman, B., Plaisant, C., Cohen, M., Jacobs, S., Elmqvist, N., \& Diakopoulos, N. (2016). Designing the User Interface: Strategies for Effective Human-Computer Interaction, $6^{\text {th }}$ Ed. University of Maryland.

Sweller, J., Ayres, P., \& Kalyuga, S. (2011). Cognitive load theory. New York: Springer

Stankova, E. N., Barmasov, A. V.. Dyachenko, N. V.. Bukina, M. N., Barmasova, A. M., \& Yakovleva, T. Y. (2016). The use of computer technology as a way to increase efficiency of teaching physics and other natural sciences.Lecture Notes in Computer Science (including subseries Lecture Notes in Artificial Intelligence and Lecture Notes in Bioinformatics). 9789, 581-594.

Toenders, F. G. C., De Putter-Smits, L. G. A., Sanders, W. T. M., \& Den Brok, P. (2017). Improving physics teaching materials on sound for visually impaired students in high school. Physics Education. 52(5)

Tomita, K. (2017). Does the Visual Appeal of Instructional Media Affect Learners' Motivation Toward Learning? TechTrends. 1-10. 
Tosho, A., Mutalib, A. A., \& Abdul-Salam, S. N. (2016). Conceptual design model of instructional interfaces: Courseware for inclusive education system (IID4C) distance learning. International Journal of Distance Education Technologies, 14 (4), pp. 68-82.

Ward, J. (2016). Are you ready for the fourth industrial revolution? Australian Mining. 108(11). 36-37.

Walsh, T., Petrie, H., \& Odutola, O. (2014). Developing interactive systems for different cultures: Issues of assessing user experience with visual materials. Proceedings of the 26th Australian Computer-Human Interaction Conference, OzCHI 2014, pp. 470-479. 